Columbia Law School

Scholarship Archive

1976

\title{
The Definition of Disability in Social Security and Supplemental Security Income: Drawing the Bounds of Social Welfare Estates
}

Lance Liebman

Columbia Law School, lliebman@law.columbia.edu

Follow this and additional works at: https://scholarship.law.columbia.edu/faculty_scholarship

Part of the Disability Law Commons, and the Social Welfare Law Commons

\section{Recommended Citation}

Lance Liebman, The Definition of Disability in Social Security and Supplemental Security Income: Drawing the Bounds of Social Welfare Estates, 89 HARV. L. REV. 833 (1976).

Available at: https://scholarship.law.columbia.edu/faculty_scholarship/2135

This Article is brought to you for free and open access by the Faculty Publications at Scholarship Archive. It has been accepted for inclusion in Faculty Scholarship by an authorized administrator of Scholarship Archive. For more information, please contact scholarshiparchive@law.columbia.edu. 


\section{HARVARD LAW REVIEW}

\section{THE DEFINITION OF DISABILITY IN SOCIAL SECURITY AND SUPPLEMENTAL SECURITY INCOME: DRAWING THE BOUNDS OF SOCIAL WELFARE ESTATES}

\section{Lance Liebman *}

Federal aid to the disabled is a vast enterprise; over nine billion dollars are annually paid to five million beneficiaries. In this Article, Professor Liebman points out how the ad hoc nature of social welfare legislation and programming has resulted in a system that produces inconsistent and sometimes inequitable determinations of disability. The present system, he argues, draws significant economic and social distinctions among the disabled, as well as distinctions between the disabled and the unemployed, that have been inadequately explained and justified. By focusing on worker expectations generated by the administration of our disability programs, and on the structural relationships established between the different programs, Professor Liebman suggests a set of principles to guide future legislative developments and judicial decisions.

$7 \mathrm{HE}$ American social welfare system consists of the accumulated expressions of intermittent liberal-reformist momentum. Statutory guarantees have provided increasingly broader protection for workers against income loss caused by declines in capacity to work or in labor market demand for services. But this legislation has rarely been accompanied by systematic discussion of the appropriate scope and function of public protection. Programs are designed and recommended by assorted groups of the affected and the committed. Then, when the votes are available, when a need is felt, when a platform is required, new arrangements make their way toward law. ${ }^{1}$

* Assistant Professor of Law, Harvard Law School. B.A., Yale, rg62; B.A., Cambridge, 1964; LL.B., Harvard, 1967.

${ }^{1}$ For discussion and analysis of America's inconsistent path toward social welfare protection, see R. Lubove, The Struggle for Social Security ig00-I935 (I968); G. Steiner, The State of Welfare (i97I); F. Prven \& R. Cloward, Regulating the Poor: The Functions of Public Welfare (x97r); The Princeton Symposium on the American System of Social Insurance (W. Bowen ed. I968); R. Levy, T. Lewis \& P. Martin, Cases and Materials on Social Welfare AND THE INDIVIDUAL (I97I) ; Bok, Emerging Issues in Social Legislation: Social Security, 80 HARv. L. Rev. 7r7 ( 1967$)$. Concerning our processes and style for deciding such questions, the story of the abortive Family Assistance Plan is enlighten- 
This disjointed political process has three consequences. First, citizens have difficulty understanding the social welfare system. Programs are complicated, misleading, and often incompatible. It is hard for an individual to determine his eligibilities, and impossible for him to discern a consistent rationale for those eligibilities. It is all too easy for a recipient to believe that his situation is unfair: that he is discriminated against or that others with no greater claim receive better treatment. ${ }^{2}$ Second, many important issues of eligibility are not resolved by Congress. In effect, these decisions are delegated to federal and state administrative agencies and to the courts. ${ }^{3}$ In the absence of legislative guidance, however, such delegation is bound to produce inconsistent results since agencies and courts have no generally accepted theoretical assumptions by which to structure the boundaries of social welfare protection. ${ }^{4}$ Third, a desultory social welfare system tends toward permanence. Complicated, compartmentalized programs encourage tenacious defense of specific advantages. Thus efforts for evaluation and alteration are denied broad political support. 5

We very much need theories of welfare state protection: reasons why Smith is paid and Green not, or why Smith's check comes only if he labors and Green's only after a lecture from a social worker. Some commentators, however, have argued to the contrary, contending that the lack of theoretical underpin-

ing. A reasonably complete account can be assembled from the quite different perspectives of D. Movninan, The Politics of a Guaranteed Income (1973); V. \& V. Burke, Nixon's Good DeEd: Welfare Reform (1974); H. Aaron, WhY Is WeLFARE So HaRd to ReForM? (I973).

${ }^{2}$ See generally M. Barth, G. Carcagno \& J. Palmier, Toward an Effective Income Support System: Problems, Prospects, and Choices (1974); D. Moyninan, supra note I, at I7-60; Subcommitree on Fiscal Policy, Joint Economic Commattee, 92D Cong., 2D Sess. \& 93D Conc., ist Sess., Studies IN Public Welfare (Comm. Print I972-73); J. Handler, Reforming the Poor: Welfare Policy, Federalism, and Morality (1972); F. Wiseman, "Welfare," movie shown on National Educational Television, September 24, I975.

${ }^{3}$ See, e.g., Rosado v. Wyman, 397 U.S. 397,408 (1970) (state discretion in fixing "standard of need"); Jefferson v. Hackney, 406 U.S. 535 (1972) (state discretion in determining relative benefit levels for different programs); New York State Dep't of Social Servs. v. Dublino, 4I3 U.S. 405 (I973) (state discretion in determining and administering work requirements).

${ }^{4}$ The AFDC program in particular has generated conflicting judicial assessments of legislative purpose. Compare King v. Smith, 392 U.S. 309, 325 (1968) (Warren, C. J.), with Shapiro v. Thompson, 394 U.S. 6I8, 645 (I969) (Warren, C. J., dissenting). Compare Carleson v. Remillard, 406 U.S. 598 (1972) (Douglas, J.), with Wyman v. James, 400 U.S. 309 (I97r) (Blackmun, J.). Compare Rosado v. Wyman, 397 U.S. 397 (I970) (Harlan, J.), with New York State Dep't of Social Servs. v. Dublino, $4^{\mathrm{r} 3}$ U.S. 405 (I973) (Powell, J.).

${ }^{5}$ See generally H. AARoN, supra note $\mathrm{I}$, at $3^{\mathrm{I}-46}$. 
nings permits the social welfare system to pay more to the poor than it would if programs and their purposes were better understood, and that current programmatic confusion is therefore desirable. ${ }^{6}$ But this analysis is unsound, even by its own resultoriented standards. Undisciplined social programming may help some individuals, but it neglects others, and the latter group are often among those least able to fend for themselves economically, politically, and bureaucratically. ${ }^{7}$ Incoherent programs may pay out a great deal of money, but they are politically vulnerable in times of fiscal crunch because they make satisfaction of recipients' claims a matter of charity rather than of right. Development of a principled theory of welfare state protection, therefore, is more than pursuit of the hobgoblin of consistency. It is absolutely necessary if we are to achieve fair and comprehensive income protection commitments that are secure against changing politics.

Two giant federal programs, Social Security and Supplemental Security Income (SSI), provide benefits to persons permanently and totally disabled. ${ }^{\mathrm{s}}$ Within each of these statutory schemes, a finding of "disability" serves the function of admitting a recipient to a favored status in the welfare state. Therefore, the conditions of qualification imposed by Congress, the Social Security Administration, and reviewing courts should tell us something about our ideas of desert and priority in social welfare protection. By examining how these three institutions have defined disability, and have thereby drawn the boundaries of coverage and eligibility under the two statutes, this Article

' See B. Blechacan, E. Gramitch \& R. Hartman, Setting Nationat PriORIrIes: THE I975 BuDGET I87-89 (Brookings Inst. I974); Wall St. J., July 3, I975, at 6 , col. 3 (interview with Gilbert Steiner, Director of Government Studies at the Brookings Institution).

${ }^{7}$ To the extent that rules and procedures are complicated, those with greater ability or will to master the system obtain more funds. To the extent that results vary capriciously, those who can influence unprincipled political decisions do best. To the extent that unchecked discretion is lodged in bureaucrats, those who can pressure them prevail. Thus, those who cannot deal with bureaucracies are treated badly even by the one system which purports to be concerned with them. See M. Barth, G. Carcagno \& J. Palmer, supra note 2; Subcommittee on FiscaI Policy, Jonvt Economic Comomitree, Studies in Public Welfare, Paper No. 5, Part I, "Welfare - An Administrative Nightmare" (Comm. Print I972); Liebman, Social Intervention in a Democracy, 34 The Pub. Interest I4 (I974).

${ }^{8}$ See 42 U.S.C. $\S 423$ (I97o) (Social Security disability program); id. $\S \S \mathrm{I3} 8 \mathrm{I}-$ 85 (Supp. III, I973) (Supplemental Security Income for the Aged, Blind and Disabled). In fiscal year 1974, approximately 3,700,000 persons received more than 7.5 billion dollars in Social Security disability benefits, see Mathews v. Eldridge, 44 U.S.L.W. 4224, 4226 n.x (U.S. Feb. 24, I976); 38 Soc. SEc. Bull. 3 I (I975), and another $I, 300,000$ received approximately $I .8$ billion dollars in SSI benefits by reason of disability or blindness, see N.Y. Times, Feb. 27, 1976, at 32, col. 2. 
explores the principles that underlie our social welfare system. These principles are then applied in an attempt to delineate boundaries more appropriate than those that now define the Social Security and SSI welfare estates.

\section{Sociar Security Disability}

"Social Security" was established in I935. A payroll tax, with proceeds earmarked for a trust fund, was imposed on employees and employers. ${ }^{10}$ By I940, persons who had worked enough days under Social Security to "earn" a pension began to retire.11

${ }^{9}$ Social Security Act, ch. 53I, 49 Stat. 620 (I935) (codified at 42 U.S.C. $\$ \S$ $301-06$ (I970)). On the origins of the Social Security program, see 3 A. Schlesinger, The Age of Roosevelt: The Coming of the New Deal 297-315 (1959); E. Witte, Five Lectures on Social Security (195 I); A. AltMieyer, The Foratative Years of Social Security (Ig66).

${ }^{10}$ Social Security Act, ch. 53I, tit. VIII, § 80x, 49 Stat. 636 (I935) (tax on em. ployees of $\mathrm{I} \%$ of wages, escalating in steps to $3 \%$ after $\mathrm{r} 948$ ); id. tit. IX, $\S$ gor, 49 Stat. 639 (r935) (similar tax on employers). The term "trust fund" was first employed in the Social Security Act Amendments of r939, tit. II, ch. 20r, 53 Stat. $\mathrm{I}_{362}$ (I939). Social Security is actually two programs, one that taxes and one that spends. In a neat sleight of hand, President Roosevelt took both to the public as one arrangement, an image essential to the message that the program was like a contract, and that individuals were depositing funds for their own later need. The legislation was drafted in an atmosphere of concern about Supreme Court review of the program, fueled by the Court's earlier invalidation of the railroad retirement scheme, see Railroad Retirement Bd. v. Alton R.R., 295 U.S. 330 (r935). The Committee on Economic Security, which prepared the legislation, concluded that Social Security's chances would be increased if its taxing and pension-paying components could be bifurcated. At least some evidence for this prediction came from a reliable source:

In I934, when Frances Perkins had confided to Justice Stone her worries about the constitutionality of a social-security system, Stone whispered back, "The taxing power of the Federal Government, my dear; the taxing power is sufficient for everything you want and need."

3 A. Schrestnger, The Age of Roosevelt: The Politics of Upheaval 398 (ig69). This was not the only advisory opinion on Social Security. See Roosevelt \& Frankfurter: Their Correspondence 1928-1945, at 224 (M. Freedman ed. 1967) (letter from Tom Corcoran and Ben Cohen in Washington to Frankfurter in Oxford, June 18, x934: "With Ray[mond Moley]'s help we managed to have the President call in Isaiah [Justice Brandeis] on Isaiah's last day here, to discuss the social insurance message before it became public .....").

However informed, the strategy succeeded. The Supreme Court upheld the taxing and pension programs on the same day. Steward Mach. Co. v. Davis, 3or U.S. 548 (1937) (tit. IX); Helvering v. Davis, $30 x$ U.S. 619 (1937) (tit. VIII).

${ }^{11}$ Between I936 and r940, persons who retired received a lump sum payment that was in effect the return of the Social Security taxes that they and their employers had paid. Social Security Act, ch. 53I, § 204, 49 Stat. 624 (1935). Initial retirees in 1940 had to have earned $\$ 2,000$ at covered employment on no less than five work days in five different calendar years. $I d$., ch. $53 \mathrm{I}, \S \S 2 \mathrm{IO}(\mathrm{c})(2)-(3)$, 49 Stat. 625 (1935). Eligibility now depends on having worked sufficient "quarters" at covered employment, a concept introduced in I950, see Social Security 
Each month retirees received "insurance proceeds," although of course the early recipients received far more than their own contributions, and were paid with the taxes levied on persons still working. ${ }^{12}$ From its inception, the Social Security retirement program has exhibited two general - and not entirely compatible - characteristics. On the one hand, certain features of the program, such as the relation of retirement benefits to wages earned during an individual's working years ${ }^{13}$ and the continued eligibility for benefits of retired persons with substantial assets, ${ }^{14}$ reflect an insurance theme. On the other hand, Social Security has attempted to assure a minimum income for aged citizens, for example by setting a benefit floor regardless of prior wages ${ }^{15}$ and by providing additional benefits for spouses. ${ }^{16}$

Social Security has thus been both an enforced individual sav-

Act Amendments of 1950 , ch. $809, \S 213,64$ Stat. 504-05 (I950). A "quarter" is three consecutive months during which an individual earns covered wages of $\$ 50$ or more. Id. (codified at 42 U.S.C. \& $4 \mathrm{I}_{3}(\mathrm{a})(2)(\mathrm{x} 97 \mathrm{O})$ ).

12 Social Security keeps records on earnings and tax payments credited to individual workers, but it has never had separate cash payout accounts for each wage earner. At the outset, the Administration had to devise a financial accomodation that would permit larger payments to retirees in the early years than their short participation in the program could justify. The Economic Security Committee's original plan was for the government to "borrow" these early-year taxes in order to make immediate benefit payments, and then repay the loan with interest beginning in the 1960's, but Roosevelt insisted that the infusion of general revenues (in effect paying back the original loan) be postponed until ig8o. See TwENTIETH Century Fund, Report on Old-Age Security (I938); A: Altmeyer, supra note 9, at II-26. In I950, the bookkeeping fiction of carrying the early "Ioans" with interest was dropped. Today the trust fund is at best a reserve against brief economic calamity (it contains enough money to pay benefits for only a few months if no new revenues are received), and a political safeguard for Social Security revenues against competition from other spending opportunities (no different, in that sense, from the highway trust fund). The fact that early retirees received benefits financed by funds "borrowed" from the Social Security system suggests a possible handle for appropriating general revenues to Social Security without disabusing the public of the "insurance" analogy. See Hearings Before the Senate Special Committee on Aging, 93d Cong., Ist Sess., pt. 4, at 252 (1973) (testimony of HEW Secretary Cohen) (advocating possible "Government subsidy" for "the deficit ... accrued during the transition period" to avoid having people think of Social Security "as a welfare program").

${ }^{13}$ Compare 42 U.S.C. $\S 4 \mathrm{I5}$ (a) (Supp. III, I973) (computation of "primary insurance amount" on basis of "average monthly wage"), with Social Security Act, tit. II, ch. 53I, § 202, 49 Stat. 623 (I935) (old age benefit payments based on "total wages"). As of December I0, I975, a single person whose average yearly wage for the I9 years before retirement was $\$ 5,500$ receives $\$ 304.70$ in monthly Social Security benefits.

${ }^{14}$ But earned income before the age of 72 results in diminished Social Security benefits. 42 U.S.C. $\$ 403$ (I970).

${ }^{15} \mathrm{Id} . \S 402(\mathrm{~m})$.

${ }^{16} I d$. $\$ \$ 402(\mathrm{~b})-(\mathrm{c})$. 
ings plan and a redistributive minimum-income welfare program. ${ }^{17}$ Nevertheless, the government has worked hard and successfully to persuade citizens that Social Security is insurance that has been earned and paid for by those who receive benefits. There is no conceivable doubt that responsible public authorities wished citizens to rely, emotionally and practically, on the future availability of Social Security benefits, ${ }^{18}$ even though Con-

${ }^{17}$ The argument that Social Security can best be understood as a "tax transfer" program rather than as an "insurance purchase" program was first advanced by Paul Samuelson in An Exact Consumption-Loan Model of Interest With or Without the Social Contrivance of Money, 66 J. Por. EcoN. 467 (I958). See also J. Brittain, The Payroll Tax for Soctal Securdty (1972); Campbell, Social Insurance in the United States: A Program in Search of an Explanation, I2 J. LAw \& ECON. 249 (I 969 ).

Those who believe that Social Security as packaged and operated has been immensely successful are obliged to acknowledge the accuracy of this description, but they remain passionate that moves to make the reality - that Social Security is a tax transfer program and not an aggregation of personal insurance policies - more visible would be a mistake. See, e.g., Hearings Before the Senate Special Committee on Aging, supra note I2, at 25I-52 (testimony of former HEW Secretary Cohen).

18 "The hope behind this statute is to save men and women from the rigors of the poor house as well as from the haunting fear that such a lot awaits them when journey's end is near." Helvering v. Davis, 30I U.S. 6I9, 64I (I937) (Cardozo, J.).

Among the public expressions that accompanied inception of Social Security, the following are typical:

A Federal old age insurance system, the largest undertaking of its kind ever attempted, has been organized and under it there have been set up individual accounts covering $42,500,000$ persons who may be likened to the policy holders of a private insurance company.

A Message Transmitting to the Congress a Report of the Social Security Board Recommending Certain Improvements in the Law, Jan. I6, I939, I939 THE Public Papers and Addresses of Frankitn D. Roosevelt 77 (I94I).

The Act provides for two kinds of insurance for the worker.

For that insurance both the employer and the worker pay premiums, just as you pay premiums on any other insurance policy. Those premiums are collected in the form of the taxes you hear so much about.

The first kind of insurance covers old age. Here the employer contributes one dollar of premium for every dollar of premium contributed by the worker; but both dollars are held by the Government solely for the benefit of the worker in his old age.

In effect, we have set up a savings account for the old age of the worker ....

These propagandists [employers who oppose Social Security] ... are driven in their desperation to the contemptible, unpatriotic suggestion that some future Congress will steal these insurance funds for other purposes. If they really believe what they say in the [literature being inserted by $\mathrm{cm}$ ployers in workers'] pay envelopes, they have no confidence in our form of government or its permanence. It might be well for them to move to some other nation in which they have greater faith.

Campaign Address on Joln Mitchell Day at Wilkes-Barre, Pa., Oct. 29, I936, 1936 The Public Papers and Addresses of Frankitn D. Roosevelt 548 (1938).

A similar theme permeated the program's early public literature. E.g., U.S. Comm. on Economic Securtix, What the Economic Security Program Means To You (I935). J. Douglas Brown, writing of his service on the staff of the Committee on Economic Security, has said: "[W]e wanted our government to 
gress inserted statutory language reserving the power to change the program. ${ }^{19}$ Sensible citizens have relied on these official promises in determining the extent of private provision it is reasonable for them to make. ${ }^{20}$ For its part, the government has rarely disappointed these expectations. ${ }^{21}$ The most recent congressional initiative was a 1973 law that provided for automatic increases in benefit levels to keep pace with inflation. ${ }^{22}$ This provision is presumably revocable, and thus no more significant than prior ad hoc increases which normally exceeded the rise in the cost of living. ${ }^{23}$ Yet by its very existence the escalator clause gives citizens additional practical encouragement to plan for retirement in expectation of Social Security benefits undiminished by price increases.

In the late 'forties, the Truman Administration fought and lost a battle to add compulsory health insurance to the Social Security program. ${ }^{24}$ Meanwhile, the Social Security trust fund grew, because the actuarial assumptions of the program's draftsmen proved conservative. ${ }^{25}$ When it became clear in 1953 that the Eisenhower Administration would not seek to abolish Social Se-

provide a mechanism whereby the individual could prevent dependency through his own efforts." Brown, The American Philosophy of Social Insurance, 30 Soc. SERv. Rev. I, 3 (I956).

10 The statute reserves to Congress "[ $t]$ he right to alter, amend, or repeal any provision. . . ." 42 U.S.C. $\S I_{304}$ (I970). This reservation of power underlay the Supreme Court's decision in Flemming v. Nestor, 363 U.S. 603 ( 1960 ), which held that Congress violated no constitutional requirement when it changed the Social Security law to deny benefits to a person deported for having been a member of the Communist Party, even though the person belonged to the Party and paid Social Security taxes when there was no such provision.

${ }^{20}$ Many private pension plans are integrated with Social Security. Contributions and payments drop as Social Security taxes and benefits increase. See, e.g., RETIREMENT INCOME PLAN FOR HOURLy EMPLOYees OF HARVARd UNIVERSiTy 6-8, I2 (I975). For evidence that retirement saving is substantially less than it would be without Social Security, see Feldstein, Social Security, Induced Retirement, and Aggregate Capital Accumulation, 82 J. Pox. EcoN. 905 (1974).

${ }^{21}$ See, e.g., Gambill v. Finch, 309 F. Supp. I, 2 (E.D. Tenn. I970) (discussing the few technical amendments that have reduced coverage).

${ }^{22} 42$ U.S.C. \& 4 I5 (Supp. III, I973). Actually, Social Security benefits now respond both to wage increases (part of which are merely inflation) and again to inflationary changes specifically. This "double indexing" will before very long force gigantic tax increases, and a major transfer of income from workers to retirees. Methods for correcting what is probably a legislative error are discussed in the Report of the Quadrenniax Advisory CouncII on Social Security, H. R. Doc. 94-75, 94th Cong., Ist Sess. (I975) [hereinafter cited as ADVIsORY CouncrI REPORT]. See also Feldstein, Toward a Reform of Social Security, 40 THE Pub. INTEREST 75 ( 1975 ).

${ }^{23}$ See N.Y. Times, April 8, I973, § 6, at 86, col. 6; id., Sept. 7, I973, at 44, col. I.

${ }^{24} \mathrm{See} 2 \mathrm{H}$. Truman, Memotrs: Years of Triat and Hope I7-30 (I956).

${ }^{25}$ I953 HEW ANN. REP. 29. 
curity ${ }^{26}$ residual demand for health insurance and the assurance of trust fund solvency generated proposals for Social Security protection against income loss due to serious medical disability. The first success was I954 legislation preserving the Social Security work record of disabled persons: individuals who became disabled were made eligible for retirement benefits at 65 as if they had continued to work between the onset of the disability and age $65 .{ }^{27}$ In 1956 , Congress provided that Social Security taxpayers between 50 and 65 years of age who became permanently and totally disabled should be eligible for monthly benefits as if they were already 65 and retired..$^{28}$ In I960, the age-50 requirement was removed. ${ }^{29}$ Disability insurance payments, thus annexed to the Old Age and Survivors program, are conditioned on three important findings. A claimant is required to show ( $x$ ) that he has worked at covered employment for the requisite number of quarters; (2) that his inability to work is "medical" in nature; and (3) that he is totally disabled. An examination of these eligibility requirements illuminates basic questions about the appropriate scope of the Social Security disability program.

\section{A. The Prior Work Requirement}

By requiring that a disability insurance recipient have worked at covered employment for a specified number of quarters, ${ }^{30}$ the Social Security disability program imposes a test that, at first glance, seems to measure a claimant's willingness to work for a living. Such a view is superficial, for it fails to explain why one who has achieved a place in the economic structure and is then

${ }^{26}$ See A. AltMeyer, supra note 9 , at 227-28.

${ }^{27}$ Social Security Amendments of 1954, ch. 1206, § ro6(d), 68 Stat. 1080. The so-called "disability freeze" is still part of the law, see 42 U.S.C. $\$ 416$ (i) (I970), as amended, 42 U.S.C. $\$ 4$ I6(i) (Supp. III, I973), and most disability cases concern claims both for current disability payments and for disability freeze protection against later reduction of retirement benefits because of the period out of work.

28 Social Security Amendments of 1956 , ch. $836, \S 223,70$ Stat. 815.

29 Social Security Amendments of I960, Pub. L. No. 86-778, tit. IV, $\$ 401,74$ Stat. 967. A claimant must have worked for 20 of the prior 40 quarters. If the disability occurs before age $3 \mathrm{I}$, the claimant must have worked during half of the quarters since his 2 Ist birthday, but in no event less than 6 quarters. 42 U.S.C. $\S 423$ (c) (x) (B) (Supp. III, I973).

${ }^{30} 42$ U.S.C. $\$ 423$ (c) (x) (B) (Supp. III, I973). Actually, widows and widowers can receive disability benefits based on their spouse's Social Security tax payments after age 50, even if they have not worked. Id. $\$ 402$ (e)(I)(B)(i) (I970). Children of qualified workers are also covered if they become permanently disabled before age I8. Id. $\S 402$ (d)(I)(G) (Supp. III, I973). Social Security disability thus covers some persons who may not have "declined" from a level of labor-force participation. These ancillary provisions raise issues much like those now arising under SSI disability, discussed at pp. 855-67 infra. 
medically incapacitated deserves income support more than one who is born medically unable to obtain an economic place. The person born disabled could be just as willing to work, but.he will never be eligible for Social Security disability benefits. Disability is simply bad luck, yet our system accords better treatment to those who are unlucky later in life than to those who were never lucky.

A first step toward a consistent explanation of the prior work requirement is to note its relation to the insurance aspect of Social Security. The requirement ensures that the claimant has paid the Social Security tax for a significant period. Thus benefits can be characterized not as public charity but as a return of insurance proceeds to the disability claimant who has paid tax "premiums" to purchase protection against the risk of disability. The insurance concept is not an entirely satisfactory explanation for the prior work requirement, however, for it could as easily justify coverage for all those now excluded by the requirement. We could assume that all persons undertake to pay insurance premiums if and when they work, and that the promise to pay these premiums is consideration for an insurance contract by which society agrees to protect against the possibility that an individual will become disabled after working and paying taxes, or be disabled throughout his life and so never achieve a status of taxpaying productivity. That this societal insurance concept has not been adopted indicates that we may be unwilling to regard as insurance a scheme that does not require a connection between an individual's actual contributions and the benefits he will receive.

A second possible reason for the prior work requirement could be a desire to protect the fisc against worker temptations to indolence. No empirical data support the conclusion that one who has worked will be less likely than one who has not worked to prefer a disability pension to a job. ${ }^{31}$ Such a proposition is not implausi-. ble, however, and is the sort of collective hunch on the basis of which social welfare decisions are often made.

A third explanation of the prior work requirement would be to see it as embodying a judgment that the person who has worked before becoming disabled has a stronger claim to benefits than the person who has not worked at all. This belief could not be based solely on the sad accident of the disabling event, which

${ }^{31}$ Results of the New Jersey negative income tax experiment can be read as mildly relevant data to the contrary. For example, the measured "willingness to work" seemed to vary very little according to a person's income level or prior work experience. See Work Incentives and Income Guarantees (J. Pechman \& P. Timpane ed. I975). See also L. Goodwin, Do the Poor Want to Work? (1972). 
would evoke equal sympathy regardless of timing; but it could be grounded on the notion that personal expectations and reliances are established with one's place in the workforce, and that it is significantly more disturbing to be struck from one's station than to be prevented from ever reaching it. ${ }^{32}$ Such a view would be based on the assertion that even if an individual has claims against society that are good despite his inability to make an economic contribution, as he begins to contribute he not only adds to his basic claim but also establishes a claim greater than the extent of his contributions - a claim, for example, to be protected if medical events outside his control make further contributions impossible.

No single theory can fully explain the prior work requirement. Given the payroll tax method of financing Social Security, the prior work requirement undoubtedly is linked to the insurance aspects of the program: part of total worker compensation is set aside to protect those who become disabled. The requirement is also related to work disincentive fears: an individual who satisfies the requirement has proved his willingness to labor. And the requirement accords special significance to the economic expectations generated when an individual holds a job for a substantial period of time. But at base the concept of desert implicit in the prior work requirement is the idea that in our society, although one's place is not fixed at birth or even upon completion of formal education, there should be a point at which one's station is relatively fixed - or fixed against certain unpleasant eventualities - and that a specified period of workforce participation ought to be the fixing point. ${ }^{33}$

\section{B. The Requirement of "Medical" Disability}

A claimant who meets the prior work requirement satisfies a basic condition imposed on all Social Security recipients: substantial workforce participation. To qualify for disability insurance benefits, the claimant must also demonstrate that his inability to obtain work is a result of "medically determinable" illness or injury. ${ }^{34}$ The medical disability requirement means that workers are not insured against unemployment caused by declines in capacity or willingness to work that cannot be given a medical explanation. For example, one person becomes lazy

${ }^{32}$ Cf. Chatman v. Barnes, 357 F. Supp. 9 (N.D. Okla. 1973) (state denied disability benefits to children if parents' income exceeded a specified level, but paid benefits to disabled adults whose own parents exceeded the same income limits).

${ }^{33}$ See generally L. Ratnwater, What Money BuYs (I974); C. Jencks, INEQUALITY (I972).

${ }^{34} 42$ U.S.C. $\S 423(d)(x)(A)$ (1970). 
and unreliable; another ages prematurely; a third becomes surly, and can no longer perform tasks that require cooperation with fellow workers or with the public; a fourth begins to drink heavily. The question thus presents itself: Why do we feel that medical disability provides a more compelling occasion for income protection than changes in individual capacity to work, when both events have the effect of ending the opportunity to earn?

The medical disability requirement obviously expresses some special solicitude for the sick. But this concern may only reflect the feeling that those who are "sick" have suffered an involuntary decline in working capacity. From this perspective, the medical disability requirement becomes an attempt to draw a line between voluntary and involuntary unemployment. We are prepared to support an individual whose workforce participation terminates after even minimal achievements, but only on the theorywhich the prior work requirement itself reflects - that disability benefits replace income which the worker expected to receive from his job, and are not an alternative to work. Thus the medical disability requirement enforces an iron logic: those who can work must work.

Courts reflect a determination to disqualify those who voluntarily withdraw from the workforce when they employ language that speaks of intention and control in defining "medical" disability. ${ }^{35}$ If the individual chose the affliction, they seem to say, he should be denied benefits. The courts are uncomfortable with this simplistic distinction between self-induced tribulations and catastrophic external events. ${ }^{36}$ Judges know this is an age of more complex theories of psychic causation. In addition, this version of the "medical" test does not explain how much time must have passed since the individual's choice before the conse-

${ }^{35}$ See, e.g., Osborne v. Cohen, 409 F.2d 37, 39 (6th Cir. 1969). Compare Marion v. Gardner, 359 F.2d I75 (8th Cir. I966) (Blackmun, J.) (awarding disability insurance benefits where claimant, a homosexual, was hospitalized for mental illness coupled with lack of power to control his sexual impulses), with Pierce v. Gardner, 388 F.2d 846, 848 (7th Cir. r967), cert. denied, 393 U.S. 885 (r968) (denying benefits because "the record discloses no mental illness but only a mental or personality disorder coupled with a propensity (not uncontrolled impulse) to the commission of sex offenses").

${ }^{36}$ A typical case is Judge Dooling's attempt to determine whether a claimant exhibited "voluntary resignation to alcoholism as an escape of choice from a life of daily labor" or, on the other hand, "helpless self-entrapment in an unconquerable addiction," Badichek v. Secretary of HEW, 374 F. Supp. 940, 942-43 (E.D.N.Y. I974). Compare A. MIINE, The World of Pooz 208 (I957):

"Can they fly?" asked Roo. flyers."

"Yes," said Tigger. "They're very good flyers, Tiggers are. Stornry good

"Ooo!" said Roo. "Can they fly as well as Owl?"

"Yes," said Tigger. "Only they don't want to." 
quences will be regarded as a qualifying disability. For instance, an individual may have "chosen" to begin drinking years ago, but may have become a "medically determinable" alcoholic who today cannot easily free himself from addiction. ${ }^{37}$ But despite its simplicity and its shortcomings, the "medical" label still serves as a very rough line excluding from qualification those changes in employment status that have resulted from the individual's own choices and therefore not from a random external event.

The central difficulty with the medical disability requirement has been that persons with indistinguishable physical ailments report differing degrees of physical limitation or pain, and differ as well in the extent to which they modify their behavior. ${ }^{38}$ The variety of individual reactions to illness and injury presents the Social Security Administration with a large number of difficult qualification questions. $^{30}$ The SSA often concludes that an individual is not medically disabled because for many other persons a similar injury or illness is compatible with work. ${ }^{40} \mathrm{~A}$ substantial percentage of these administrative determinations are in turn reversed by the courts, ${ }^{41}$ which have pronounced no general

${ }^{37}$ See, e.g., Wheeler v. Glens Falls Ins. Co., 513 S.W.2d x79 (Tenn. 1974) (workman's compensation case). But cf. Powell v. Texas, 392 U.S. 514, 550 (r968) (White, J., concurring in result):

I cannot say that the chronic alcoholic who proves his disease and a compulsion to drink is shielded from conviction when he has knowingly failed to take feasible precautions against committing a criminal act, here the act of going to or remaining in a public place.

${ }^{38}$ E.g., Ber v. Celebrezze, 332 F.2d 293, 296 (2d Cir. 1964) ("While the medical evidence may perhaps indicate that Mrs. Ber's physical symptoms were of a type which probably would have caused many people considerably less pain than Mrs. Ber suffered, it nevertheless amply supports her complaint that in her particular medical case these symptoms were accompained by pain so very real to her and so intense as to disable her.") ; Page v. Celebrezze, 31x F.2d 757, 762-63 (5th Cir. I963).

${ }^{39}$ See Dixon, The Welfare State and Mass Justice: A Warning from the Social Security Disability Program, r972 DukE L.J. 68I, 683 n.12. The difficulty of these individualized determinations was apparent to one perceptive commentator when the initial "disability freeze" law was enacted. See E. Burns, Soctal Security and Public Policy 124 (1956). It is not apparent even now to the Supreme Court. Sec Mathews v. Eldridge, 55 U.S.L.W. 4224, 4232 (U.S. Feb. 24, 1976) (Powell, J.):

In short, a medical assessment of the worker's physical or mental condition is required. This is a more sharply focused and easily documented decision than the typical determination of welfare entitlement. In the latter case, a wide variety of information may be deemed relevant, and issues of witness credibility and veracity often are critical to the decisionmaking process. . . .

By contrast, the decision whether to discontinue disability benefits will turn, in most cases, upon "routine, standard, and unbiased medical reports by physician specialists" ....

${ }^{40}$ See, e.g., Hayes v. Celebrezze, 3II F.2d 648, 65I (5th Cir. 1963) ("The Secretary persists in the notion that no matter how painful in fact [claimant's osteoarthritis of the spine] must be, it does not satisfy the statute.").

${ }^{41}$ In $197 x$ there were 1537 new disability complaints in the district courts and 2260 "old" disability cases awaiting disposition. In that year the courts of appeals 
rules for qualification but have instead employed the technique of finding the Secretary's evidence insufficient to support a conclusion of nonmedical disability. ${ }^{42}$

The high reversal rate could be attributed to a difference in institutional perspectives. The Secretary runs a large program, and must have rules. Attempting to implement Congress' clear purpose that benefits be provided only to those persons in fact medically disabled, the Secretary establishes hurdles that make it difficult for someone to qualify solely on the basis of a persistent assertion that he is physically incapable of work or able to work only with great pain. ${ }^{43}$ Judges, on the other hand, need not consider the program as a whole or its annual budget. Their inquiry is normally focused on an individual claimant, whose story is often sympathetic, whose perseverence in carrying the case so far is evidence of a sincere claim, and who will not be on Easy Street even if he wins the appeal.44

decided 86 disability cases, and had 69 others pending. The Secretary was affirmed in only $62 \%$ of the $197 x$ district court cases. From inception of the disability program through calendar r970, the Secretary's record in the courts of appeals was 232 affirmances and $I 62$ reversals and remands. Dixon, supra note 39 , at 700-or \& nn.92 \& 93. See also Sayers v. Gardner, 380 F.2d 940, 942-43 (6th Cir. x967); L. Jaffe, Judicial Control of Administrative Action 608 (r965); Kaufman, District Court Review of Department of Health, Education, and Welfare Decisions, 26 AD. L. REv. II3 (I974). The high reversal rate for disability cases has been cited both to show that the appellate system is fair, Richardson v. Perales, 402 U.S. 389,410 (197r) (Blackmun, J.), and to show that the initial process is dubious, Richardson v. Wright, 405 U.S. 208, 22 I (1972) (Brennan, J., dissenting). See Brudno, Fairness and Bureaucracy: The Demise of Procedural Due Process for Welfare Claimants, 25 Hastrngs L.J. 813, 826 n.4I (I974).

${ }^{42}$ An example is Wilson v. Richardson, 455 F.2d 304 (4th Cir. 1972), where the Secretary applied his crude rule - earnings of $\$ 140$ per month show an individual is not disabled, see 20 C.F.R. $\S 404.1534$ (b) (I975) - even though the claimant had held and lost eleven different jobs because employers discovered his impairments or because of the strain on his back and legs. The court reversed, saying that sometimes a record of employment can establish, instead of refute, a conclusion of disability. Similar cases include Dodsworth v. Celebrezze, 349 F.2d 3 I2 (5th Cir. 1965); Mefford v. Gardner, 383 F.2d 748 (6th Cir. 1967); Browne v. Richardson, 468 F.2d 1003 (Ist Cir. $x 972$ ); Webb v. Weinberger, 37I F. Supp. 793 (N.D. Ind. I974). These cases exhibit a modern view of how much pain and discomfort an individual must bear that is quite different from the sturdy attitude of Judge Learned Hand:

A man may have to endure discomfort or pain and not be totally disabled; much of the best work of life goes on under such disabilities; if the insurance had been against suffering, it would have read so.

Theberge v. United States, 87 F.2d 697, 698 (2d Cir. I937) (plaintiff's claim for benefits under war risk insurance policy should not reach jury).

${ }^{43}$ See, e.g., Butler v. Flemming, 288 F.2d 59I (5th Cir. I96I) ("[c]laimant could no longer even shuffle dominoes," yet Secretary denied benefits).

${ }^{44}$ Reversals seem to be a complex of $(x)$ the inherently amorphous nature of the abstract capacity-for-gainful-activity standard when applied to claimants with some quantum of residual work capacity; (2) the borderline fact 
The conflict between the Secretary and the courts on the medical disability issue exposes a broader disagreement about the nature and purpose of the Social Security program. The Secretary's Procrustean rules achieve a certain sort of fairness by regularizing discretionary determinations. From his perspective, if most persons will respond in a certain way to a particular injury or illness, then it is appropriate to assume that everyone will respond in that way. The courts have taken a contrary position that is more responsive to the insurance aspects of Social Security. Their insistence that the Secretary produce better evidence to rebut individual disability claims can be seen as a determination to interpret the program's content with attention to the expectations individuals have formed as they have participated in an on-going relationship with the United States. Relying on the government's promise of disability benefits, citizens have forsaken alternative savings arrangements. ${ }^{45}$ The individual worker believes he is protected against medical catastrophe. To him that means he will receive income-support payments if he is sick or hurt and can no longer work. He certainly does not expect that an injury which disables him will be found noncompensable (i.e., nonmedical) because most persons would be able to continue working with symptoms that are indistinguishable to the doctors' methods and machines.

The courts' concern for individual worker expectations is fully consistent with the history and conduct of the Social Security disability insurance program. When a judge reverses a denial of benefits, he should be seen as saying that the program's purpose is to assure income related to prior earnings when a claimant can make a sufficient showing of certain sorts of random bad luck, and that the showing made by the claimant is sufficient, in that most persons (I) would want to be covered if they could make such a showing; (2) would expect a disability insurance program to cover them in such circumstances; and (3) are prepared to

situations in most of the cases which fall outside [per se rules]; (3) the difficulty in assessing psychological overlay in the borderline cases; (4) the conclusory testimony of some medical advisers, which has telling effects; (5) the naturally appealing nature of the face-to-face contact, which first occurs at the hearing examiner level; (6) the presence of an attorney who in any borderline case can always make a plausible argument, and by his mere presence threatens further appeal; (7) the natural desire of an appellate body to exercise its independence, which in the SSA context can only be accomplished through ruling in favor of the claimant; (8) at the court level, judicial ignorance or simply nonacceptance of the statutory standard of disability.

Dixon, supra note 39 , at $732-33$ n.259. Of course, one thing the history of public disability insurance may show is that there are some legislative distinctions that, even if they accurately describe the categories popular perceptions would define, are extremely hard to administer cheaply and fairly.

${ }^{45}$ See pp. 838-39 \& nn.I8-20 supra. 
pay the costs of coverage for all such cases as are likely to arise. This focus on the reasonable expectations of Social Security participants suggests the need for fact-finding procedures open to allegations of pain; $;^{46}$ to assertions that a physical accident has led to changes in personality so drastic as to prevent effective work ${ }^{47}$ and to claims that an individual is disabled even if he declines a dangerous and frequently unsuccessful operation. ${ }^{48}$ The central characteristics of Social Security disability insurance should be a claimant's climb to a place in the labor force, his loss of that place due to one of a category of external risks we have decided to spread among all workers, and his current inability to achieve income without a degree of effort or suffering that persons generally would regard as unnecessary for someone with this individual's thresholds of pain and discomfort. ${ }^{49}$ These are exceedingly individualized determinations, to be sure, but they are necessary if this program is to perform its appropriate task.

\section{The Total Disability Requirement}

Even if a claimant has worked for the required number of quarters and has suffered a "medical" decline, benefits will be denied unless the fall from employability is total..$^{50}$ For example, a skilled auto mechanic whose rheumatism makes him unable to repair cars but who is still capable of performing a sedentary occupation is not covered. The statute does not insure against his decline in income, ${ }^{51}$ nor does it offer him the option of sub-

${ }^{46}$ See Ber v. Celebrezze, 332 F.2d 293 (2d Cir. I964).

${ }^{47}$ See Davidson v. Gardner, 37o F.2d 803 (6th Cir. I967).

${ }^{48}$ See Morse v. Gardner, 272 F. Supp. 618 (E.D. La. I967).

${ }^{40}$ Emphasizing this explanation for the Social Security disability program casts doubt on one group of cases in which the judges have been moved to overrule administrative denials of benefits. Sometimes, an individual is physically or mentally impaired from the beginning of his working life, but manages to accumulate the very brief work experience (theoretically, as little as $\$ 300$ in covered wages, over a period of eighteen months, see note II supra) required for Social Security coverage. If this person then applies for benefits, but cannot show that his condition has deteriorated, the theory of the program advanced above would suggest denial. Courts usually look only at the condition of the person as he appears before them, and at the technical requirements for achieving coverage. If the person now seems impaired, they are likely to reverse a denial of benefits even if the person was no healthier when working. See, e.g., Rayborn v. Weinberger, 398 F. Supp. I303 (N.D. Ind. I975).

${ }^{50} 42$ U.S.C. $\S 423$ (d) (2)(A) (1970).

${ }^{52}$ But see Hearings Before the Senate 'Special Committee on Aging, 93d Cong., Ist Sess., pt. 4, at 246 (I973) (suggestion by former HEW Secretary Cohen that persons over 55 who are able to work but "unable to engage in their customary occupation" be covered). 
sisting on a disability grant or taking a lower paying job. ${ }^{52} \mathrm{Be}-$ cause the claimant can work, he must work.

Although the Social Security statute defines total disability as "inability to engage in any substantial gainful activity by reason of any medically determinable physical or mental impairment," some workers are classified as totally disabled with no inquiry into whether they can work at other jobs. Loss of both arms or both legs, for example, is a per se case of total disability according to the Secretary's regulations. ${ }^{54}$ But unless a claimant is unlucky enough to have lost a large chunk of his anatomy, he can qualify only by showing that, in his specific case, a medical impairment has brought him within the statutory standard of inability to perform "substantial gainful activity."

I. Reasons for the Total Disability Requirement. - Two ideas compete for priority in the Social Security program. One is need. Because one of the program's purposes is to prevent destitution, it inevitably strains to conserve limited resources for allocation among the most needy. This concern for prudence not only mandates efficient identification of the most needy. It also mandates equity: an inquiry into the relative claims of possible recipients. The second concept is insurance. The government's representations have generated expectations and reliances by working persons, and the program must redeem its promises so that its ongoing commitments will be credible. The total disability requirement shows the complex interplay of these two concepts in a program plainly attempting to respond to both of them.

The total disability requirement certainly implements an intention to allocate limited resources to the most needy. Those who cannot work need more assistance than those able to obtain a job, even though it pays less than their former employment. Denial of benefits for partial disabilities also conserves resources by avoiding the substantial cost of ascertaining the precise extent of a partial disability. But efficiency is always with us, providing a reason for doing less rather than more. And Social Security is not the only potential source of support for the completely dis-

52 But cf. Stewart v. Cohen, 309 F. Supp. 949, 955 (E.D.N.Y. 1970) (suggesting that college-educated claimant might be permitted to receive benefits during a limited period of rehabilitation and training, instead of being required to accept employment as unskilled laborer, so he could again be qualified for white-collar employment).

${ }^{53}$ U.S.C. $\$ 423$ (d) (I) (A) (I970).

${ }^{54}$ See 20 C.F.R. \& 404.1502(c) (I975); UnITEd STATES DEP'T of HEW, Social Security Administration, Disabitity and Sociat Security (1965). Qualifying injuries and illnesses are listed in 20 C.F.R. ch. III, subpt. P, app. (1975). For evidence that Congress has approved qualification on the basis of such "pure" medical determinations, see Dixon, supra note 39 , at 704 n.Iro. 
abled. Other programs - such as general relief or AFDC identify their beneficiaries principally in terms of need. Therefore, neither administrative efficiency nor an attempt to assist the most needy can fully explain (I) why Social Security disability denies benefits to those only partially disabled, or (2) why we pay those who are totally disabled with relatively generous Social Security checks rather than with AFDC or general relief grants. A totally disabled person who has never worked, or a person whose alleged total disability is not medically cognizable, may be just as needy as a Social Security disability recipient - yet we tell him to look elsewhere for income protection. ${ }^{55}$

It is tempting to see the total disability requirement as an exemplification of a principle of equity. In our economy, some individuals must perform disagreeable and low-paid jobs. Since a partially disabled person can by definition perform at least this sort of job, it may be thought to be inequitable to treat him as having a claim on society greater than that of a person who has always worked at a lesser-paying job. Thus, if we focus only on need, it may seem unreasonable to differentiate between similarly situated persons merely because one has suffered a partial medical disability.

The difficulty with this argument from equity is that we pay benefits to those "totally" disabled for a medical reason who have satisfied the prior work requirement, but not to persons unable to work who have never worked or whose difficulty is not "medical." The very existence of the Social Security disability program is an assertion that the person whose employment history shows a medical decline from earlier achievement deserves benefits more generous and less burdened by bureaucratic indignities than the person who has not previously worked. The disabled person has been encouraged to think of the Social Security taxes deducted from his wages as a purchase of insurance against income loss from medical catastrophe. That the disabled claimant is no worse off than some who clearly have no Social Security claim is irrelevant: it is prior work and medical catastrophe, not level of need, on which the disabled person urges his right to Social Security. Because Social Security has such a substantial insurance component - responding to an individual's personal work record, to the expectations created by employment, and to

\footnotetext{
${ }^{55}$ See Coleman v. Gardner, 264 F. Supp. 714, 718 (S.D.W. Va. 1967):

In this instance, plaintiff's youth and sketchy work record mitigate [sic] against his claim. The Act's disability benefit provisions are designed primarily to aid workers who, after having made a contribution to the nation's work force, are unable to continue. It is not intended, nor should we allow it to become, a substitute for the various Federal and State direct relief programs for the socially deprived.
} 
the particular causes of his present difficulties - arguments based solely on equitable treatment of those currently in similar economic circumstances cannot fully explain the program's basic rules or provide sufficient guidance in resolving the ambiguities of the statute.

Thus no logic requires that the Social Security program deny protection against partial declines in earning power. The program excludes these declines because funds are limited and because the exclusion avoids a category of difficult administrative determinations. Denying benefits for partial disability is acceptable, however, because official messages have always made clear that only "total" disability will be compensated.

2. The Job Gap Cases. - The tension, implicit in Social Security, between providing income support for an equitably defined subgroup of the needy and satisfying the officially encouraged expectations of wage-earners, is best illustrated in the "job gap" cases. An individual enters the job gap when he suffers an unquestioned medical disability that prevents continuation of pre-injury employment, when he remains physically and emotionally able to do certain other jobs, but when he cannot obtain another job. Jobs may be unavailable because: ( $\mathrm{I}$ ) they do not exist where the claimant lives; ${ }^{56}$ (2) employers incorrectly conclude that the disability prevents performance of the job; ${ }^{67}$ or (3) employers hire non-disabled persons who are younger, or abler, or safer risks. ${ }^{58}$ Such a worker is medically disabled; the disability is a but-for cause of his unemployment; and yet his disability alone does not keep him from working. It is disability as well as labor market conditions that have left him unemployed.

The first extended analysis of the job gap problem appeared in the influential case of Kerner v. Flemming ${ }^{50}$ Kerner had been a self-employed furniture repairman. After suffering a heart attack and serious diabetes, he could only do "light, sedentary work." His willingness to do such work was unquestioned. To the extent jobs were available, however, employers chose not hire a 60-yearold diabetic with a history of heart disease. The Secretary denied benefits, but the Court of Appeals for the Second Circuit reversed. Judge Friendly interpreted the disability requirement as follows: "What can applicant do, and what employment opportunities are there for a man who can do only what applicant can

\footnotetext{
${ }^{56}$ E.g., Wright v. Gardner, 403 F.2d 646 (7th Cir. rg68).

${ }^{57}$ See, e.g., King v. Gardner, 39x F.2d 40x, 404-05 n.7 (5th Cir.) (dictum), vacated on rehearing, 39I F.2d 40I, 4IO-xI (5th Cir. I967) (en banc).

${ }_{58}$ E.g., Caraballo v. Secretary, 346 F. Supp. 93 (D.P.R. I972).

${ }^{59}{ }_{283}$ F.2d 9 r6 (2d Cir. I960) (Friendly, J.).

${ }^{80}$ Id. at 9 I8.
} 
do." ${ }^{\prime 61}$ Kerner gradually received wide, ${ }^{62}$ though not universal, ${ }^{63}$ assent. Courts placed on the Secretary the burden - once a claimant showed a disability making him unfit for his former work - of producing evidence sufficient to show not only what work the claimant was still capable of performing, but also that obtaining such work was a realistic possibility, and realistic near the claimant's home. ${ }^{64}$

Only Judge Wisdom, in a perceptive dissent from Fifth Circuit agreement with Kerner, ${ }^{65}$ recognized the potential application to job gap cases of a principle of equity that would justify exclusion from the program of those who are only partially disabled. He acknowledged the economic distress of medically impaired persons in the job gap, but contended that it was not distinguishable from the need of every non-disabled person in the job gap. Non-disabled persons who cannot find work, Judge Wisdom argued, must rely on unemployment insurance or, when that expires, on general public assistance, and he found neither equitable nor statutory authority for treating medically impaired persons any differently. ${ }^{66}$

${ }^{B 1} 283$ F.2d at $92 \mathrm{I}$. Kerner himself apparently did not benefit from his doctrinal victory. See Kerner v. Celebrezze, 340 F.2d 736 (2d Cir.), cert. denied, 382 U.S. 86I ( 1965$)$.

02 See, e.g., Baker v. Gardner, 362 F.2d $864^{\circ}$ (3d Cir. I966); McMuller v. Celebreeze, 335 F.2d 8 II (9th Cir. I964), cert. denied, 382 U.S. 854 (1965); Torres v. Celebrezze, 349 F.2d 342 (Ist Cir. I965).

${ }^{63}$ See, e.g., Loftis v. Ribicoff, I93 F. Supp. 469 (W.D. Mo. I96I).

${ }^{64}$ An extreme version of the Kerner issue was presented in Sayers v. Gardner, 380 F.2d 940 (6th Cir. I967). There, claimant could not get jobs because employers said they would have an "insurance problem" if they hired her, and the court reversed the Secretary's conclusion that claimant could in fact work. Obviously, the Secretary was making one decision (whether claimant could or could not work), the employer was making a second (whether, among the candidates for some particular job, he and his workmen's compensation carrier preferred someone who had not previously been sick), and the court was making a third decision (whether a reasonable disability statute would regard this individual's reasons for being unemployed as "medical"). For an example of a decision, reflecting an appreciation of actual labor market conditions, see Hanes v. Celebreeze, 337 F.2d 209 (4th Cir. I964). The claimant had a patronage job as custodian at a public building, but the court rejected the Secretary's conclusion that performing that job - which in fact his wife and son often performed for him - showed that he was not disabled. Accord, Stark v. Weinberger, 497 F.2d 1092 (7th Cir. 1974) (Stevens, J.).

${ }^{65}$ King v. Gardner, 39I F.2d 40I, 405 (5th Cir. I967) (Wisdom, J., dissenting). Even though Judge Wisdom failed to persuade the majority to deny benefits to King, her victory was Pyrrhic. She was ultimately denied benefits when while her case was still being litigated - Congress adopted Judge Wisdom's position in the 1967 amendments to the Social Security Act, see p. 853 infra. See King v. Finch, 428 F.2d 709 (5th Cir. I970).

${ }^{60}$ Perhaps surprisingly, the commentators generally sided with Judge Wisdom. 
But Judge Wisdom's position does not differentiate among the needy, or among the programs we have established to assist them. Because he considered Social Security disability benefits to be no more than a general relief dole, and to be unaffected by the program's insurance image and its role in framing worker expectations, Judge Wisdom saw no inconsistency in asking why a worker cannot get a job now without inquiring as to why he lost the job he had. No doubt Congress did not mean to pay disability benefits to a worker who loses his job because of automation or a demand contraction: the medical disability requirement is proof of that. Yet in arguing against Kerner, Judge Wisdom ignored the fact that except for a medical misfortune, the job gap claimant would have been working. Furthermore, Judge Wisdom's position proves too much. It is, of course, based on the assumption that Mr. Kerner can work, but virtually every disabled person can do something for which another person will pay. He is "totally" disabled because the market value of his labor, given such alternatives as machines and healthy persons, is so low. Indeed, disability is as much a function of social choices as it is a result of illness or injury. We impose - arbitrarily, but sympathetically and wisely - a barrier that says, "Work less valuable than this price shall not be done for money in this society. If that is all you can do, it is better that you be regarded as unemployed or disabled." Thus, Mr. Kerner could not work, and since his removal from the workforce was occasioned by medical disability, he should have received benefits. ${ }^{67}$

This sense of disability as society's categorization of those honorably disqualified from work is adumbrated in the pain and suffering cases, which the system normally deals with under the rubric of the medical disability requirement, ${ }^{68}$ but which reflect an implicit judgment about total disability. The claimant alleges that a certain injury is so painful that he cannot perform any work.

See, e.g., Rowland, Judicial Review of Disability Determinations, 52 GEo. L.J. 42, 79 (I963); Note, Social Security Diability Determinations: The Burden of

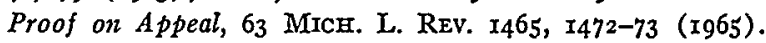

${ }^{B 7}$ Recognition of the attitude suggested above can be seen in the so-called "wolf from the door" cases. Occasionally under Social Security disability, courts have disagreed with the Secretary's conclusion that an individual's earnings history demonstrates that he is not disabled. The judges have said that the need to eat will force some individuals to work even though they qualify as disabled. The conclusion must be that the physical capacity to do work for which the market will pay does not establish the absence of a disability, but that at least sometimes a judgment independent of the market's can be made that the person need not work. See, e.g., Flemming v. Booker, 283 F.2d 32I, 324 (5th Cir. I960); Hanes v. Celebreeze, 337 F.2d 209, 213-14 (4th Cir. 1964); cf. United States v. Spaulding, 293 U.S. 498, 505 (I935) (World War I risk policy).

${ }^{68}$ See pp. $842-45$ supra. 
The Secretary concludes that, because similar injuries have not completely disabled other workers, inability to work is caused by a failure of will, and hence he labels the disability as nonmedical. When courts review those cases, their opinions express a social judgment as to whether that level of pain is a sufficient reason to quit work altogether.

The obvious rightness of the Secretary's per se rules for total disability - automatic qualification for a person who has lost both arms, for example ${ }^{69}$ - also suggests that our definition of disability incorporates common expectations and shared values about what infirmities a person ought not to have to bear and keep working. As to persons so disabled, we say, in essence, "No one expects you to work any longer. If this happens to you, you can stop work and receive Social Security benefits."

3. The Job Gap Statute. - The Kerner debate was possible because the job gap question was left open by the Social Security statute. Once a judicial consensus developed, of course, Congress might have left that consensus undisturbed. Instead, it overruled the judges who followed Kerner. In 1967 disability insurance was amended to provide that an impairment could not be considered a "total" disability unless it rendered the claimant unable to perform not only his previous work, but also "any other kind of substantial gainful work which exists in the national economy, regardless of whether such work exists in the immediate area in which he lives, or whether a specific job vacancy exists for him, or whether he would be hired if he applied for work." 70

In its Report accompanying the legislation, the House Ways and Means Committee expressed "concern about the rising cost of the disability insurance program and the way the definition of 'disability' has been interpreted." "11 Cost may have been a factor in the legislative calculus, although what was at stake was a tiny part of the entire Social Security program. Rather, at least some legislators must have felt disserved by what the Senate Finance Committee referred to as "some of the court decisions on the subject." 72 The betrayal presumably was accomplished by judicial admission to "disabled" status of individuals with inferior claims, who might just be malingering, or whose need for money - even

${ }^{60}$ See p. 848 \& n.54 supra.

${ }^{70}$ Social Security Amendments of 1967 , Pub. L. No. $90-248, \S$ I58(d) (2) (A), 8 I Stat. 868 (codified at 42 U.S.C. $\& 423$ (d) (2) (A) (I970)).

${ }^{71}$ H.R. REP. No. 544, goth Cong., Ist Sess. 28 (I967). The Senate defeated the anti-Kerner legislation, II3 CoNG. Rec. 16,746 (daily ed. Nov. 17, I967), but then accepted the Conference Committee's restoration of it, II3 CoNG. REC. 35,924 (daily ed. Dec. 15,1967 ).

${ }^{72}$ See S. REP. No. 744, goth Cong., ist Sess. 47-49 (x967). 
if real — ought not to be met with checks carrying the very special dignity associated with Social Security.

4. Disappointed Expectations. - It is, of course, possible to maintain Judge Wisdom's distinction between Kerner and the person so sick that he cannot physically perform any job that pays the minimum wage, and possible, too, to regard Kerner as no different from unemployed persons whose abilities have not declined. But in light of the concepts underlying Social Security and its disability component, Kerner and its progeny ought not to have been disapproved. ${ }^{73}$ The Social Security disability program expresses not only a present willingness to support the incomes of certain needy people. It is a complex interrelated scheme, clearly intended ( $\mathrm{I}$ ) to reassure workers who fear the economic consequences of disability; (2) to enforce prudence by taxing their labor as a means of financing protection; and (3) to pay benefits as a matter of right. Social Security disability may not be a private insurance contract, but it obviously reflects a congressional purpose to create expectations and behavior exceedingly similar to what would be brought about by mandatory private insurance.

To visualize Social Security disability protection as a function of worker expectations is to see a way through the Kerner problem. If an individual bought private insurance against total medical disability and then became so sick that he could not do his former job, would he not expect to be paid - even if he could still perform some work but could not obtain a job? What point would insurance have, if not to pay when sickness leads to zero income? The insured might be less "needy" because of his theoretical capacity to work, but the point of the insurance would surely be income continuation if labor could not produce cash. We would be outraged if the small print in a Mutual of Omaha policy denied payments to Mr. Kerner. Because the United States, in its Social Security program, has tried to be Mutual of Omaha,

${ }^{73}$ The battle over Kerner continues. The 1975 Social Security Advisory Council adopted former HEW Secretary Cohen's suggestion that persons over 55 be eligible for disability benefits when unable to engage in their "customary occupation," see note 5 I supra, instead of the present requirement of inability to engage in any substantial occupation. See ADvisory CouncII Report, supra note 22, at 38-40. The Council's recommendation was that persons in the job gap receive 80 percent of the benefits paid to those who now qualify as disabled. This increase in coverage would cost the nation o.r3 percent of the total payroll subject to the Social Security tax. The durability of the judicial preference for the Kermer result is suggested by district court cases in which a close look at "substantial evidence" review suggests that the judge is attempting to exhume Kerner even after its clear legislative burial. See, e.g., Thomas v. Richardson, 37I F. Supp. 362, 363-64 (S.D.N.Y. I974); Lashbaugh v. Gardner, 294 F. Supp. II43, II45-46 (D. Ore. rg68). But see, e.g., Brown v. Finch, 429 F.2d 80, 82-83 (5th Cir. 1970). 
judicial interpretation of the statutory ambiguity should mirror adjudication of a claim against a private insurer. ${ }^{74}$

Feelings of security, of status, and of assurance are important ingredients of human welfare. At the core of Social Security is a promise by the polity that a degree of labor force achievement justifies an expectation of income security against medical disability. In the 1967 amendments, Congress casually disregarded Mr. Kerner's reasonable expectations as a wage-earner, had he contemplated the possibility of disabling illness, and his expectations as a sick person when he sought the benefits toward which he thought he had contributed. It may be that the denial of benefits for partial disability illustrates a situation where the burdens of administration constrain the achievement of a social welfare system whose coverage is fully appropriate to its logic. But if the program remains focused on total disability, then it should cover all cases in which a medical cause leads to total unemployment, even if the claimant might be put to work by an ideal labor market. Social Security seeks to gain for the nation the increase in welfare incident to a broad expectation of protection. To keep that faith, it must meet the expectations thus engendered.

\section{SSI DISABILITY}

Millions of people medically unfit for labor are not eligible for Social Security disability: persons born with a disability, disabled during childhood, or disabled as adults before achieving sufficient experience at covered employment. From I950 to I972, the states provided income support to disabled persons unable to qualify for Social Security under one of the federally subsidized "categorical" aid programs, ${ }^{75}$ which also included aid to the aged, the blind, and single parents. ${ }^{76}$ In 1972 , after considering the Ad-

${ }^{74}$ For a case under a private insurance policy, but otherwise indistinguishable from Kerner, see Snelson v. Pennsylvania Life Ins. Co., 65 Ill. App. 2d 4I6, 212 N.E.2d 873 (I965). Snelson had worked as a bricklayer until he was injured. After the injury, doctors said there was a fair amount he could do, but he testified that when he went to the "unemployment place," he was told they "had guys in better shape . . . and not to come back." The policy insured against "total disability and total loss of time." The court held for the claimant, saying that "when a man is no longer able to do his accustomed task and such work as he has only been trained to do, and upon which he must depend for a living, he is totally disabled within the meaning of the policy in question." Id. at 429, 2 I2 N.E.2d at 880. See also Dixon v. Pacific Mut. Life Ins. Co., 268 F.2d 812, 815-I6 (2d Cir. 1959), cert. denied, 36x U.S. 948 (I960) (permitting a surgeon to recover on his private disability insurance policy when he suffered an injury to his hand that would have permitted him to continue work only as a general practitioner).

${ }^{75}$ See Social Security Act Amendments of 1950 , ch. 809, § 35I, 64 Stat. 555 .

${ }^{76}$ See 42 U.S.C. $\$ \S 30 I-06$ (I970) (aged); id. \$\$ 60I-IO (dependent children); id. $\S \S$ I20I-06 (blind). 
ministration's welfare reform proposals for two years, Congress concluded that despite universal rhetorical castigation of the present welfare system, there was no Senate majority for any particular alternative. ${ }^{77}$ In the pain of that awareness, Congress retreated to a 194-page assortment that the newspapers treated as technical amendments to the Social Security Act. ${ }^{78}$ Thus, little fanfare accompanied the most important federal income-support legislation since enactment of Social Security in $19355^{70}$ The amendments merged categorical aid for the aged, blind, and disabled, and created a new federal program called Supplemental Security Income (SSI) ${ }^{80}$ Congress thus separated income maintenance for these three groups from Aid to Families with Dependent Children (AFDC).

In a short time, SSI became a major undertaking. Only a year after the program's inception, benefits were being paid to four million persons, and the President's 1976 budget projected expenditures of 5.5 billion dollars for SSI. ${ }^{81}$ Qualification for SSI benefits by virtue of age or blindness is determined by objective standards of age or diminished sight. ${ }^{82}$ Eligibility by reason of disability cannot be so easily determined, however, and cases testing the ambiguous statutory language inevitably pose difficult questions about the extent to which the nation has committed itself to an assurance of minimum income.

\section{A. The Significance of SSI Qualification}

It is important to recognize at the outset that the new SSI definition of disability is of great significance to a large number of persons. Before SSI, qualification for Social Security disability meant relatively generous benefits, payments as a matter of right,

${ }^{77}$ See II8 CoNG. REc. $16,801-69$ (Oct. 4, I972); id. at I6,92I-I7,032 (Oct. 5, I972); id. at $18,495-500$ (Oct. I7, I972). For descriptions of the proposed reform plan, see H.R. REP. No. 92-23I, 92d Cong., Ist Sess. (I97I); S. REP. No. 92-1230, 92d Cong., 2d Sess. (1972) ; CoNF. Rep. No. 92-I605, 92d Cong., 2d Sess. (1972).

${ }^{78}$ Social Security Amendments of I972, Pub. L. No. 92-603, 86 Stat. 1329; see, e.g., N.Y. Times, Oct. I8, 1972, at 48, col I.

79 The only other substantial additions to the federal income-support effort were Social Security disability, see pp. 839-40 supra, and "categorical" disability aid, see p. 855 supra. Of course poor persons receive immense financial benefit from Medicaid, Medicare, and Food Stamps, but these programs support only certain sorts of expenditures.

${ }^{80}$ Social Security Amendments of 1972 , Pub. L. No. 92-603, $\$$ I601-02, 86 Stat. 30I-02 (codified at 42 U.S.C. $\$ \S I 38 I-82$ (Supp. III, I973)).

${ }^{81} 38$ Soc. Sec. Buld. 43 (Oct. I975); The Budget for the United States GOVERNMENI: FISCAL YEAR I976, at 244 (1975).

${ }^{82}$ The age qualification is 65,42 U.S.C. $\$ 1382 c$ (a) (I) (A) (Supp. III, I973), and "blindness" is defined as "central visual acuity of $20 / 200$ or less in the better eye with the use of a correcting lens," id. $\S 1382 \mathrm{c}$ (a) (2). 
and respectable status as a former taxpayer struck from the workforce by medical catastrophe. Extensive litigation demonstrated both that the statutory standard of disability was hard to apply and that attaining the special status of a Social Security recipient was important to many persons. At the same time, millions of persons were receiving disability benefits from state welfare departments under the categorical disability program. The states established disability definitions that were no less ambiguous than the federal requirements, ${ }^{83}$ but there was virtually no litigation. ${ }^{84}$ The reason, presumably, was that most persons not called "disabled" instead received AFDC or general relief assistance, and were indifferent about which "welfare" category was the source of their support.85

SSI changed that. Whether one is "disabled" or "on welfare," previously only a technical distinction between categorical aid programs, is now a matter of the greatest practical, moral, and emotional significance. This is because our social welfare programs fall along a continuum that may be crudely described as running from legitimacy to stigma, from entitlement to gratuity. Before 1972 , disabled persons ineligible for Social Security benefits were located with AFDC recipients at the least dignified position on the continuum. ${ }^{86}$ Now, with SSI, they have been moved toward

\footnotetext{
${ }^{83}$ See, e.g., 23 IrL. REv. STAT. § 3-r (Ig68) ("physical or mental impairment, disease, or loss which is of a permanent nature and which substantially impairs . . . ability to perform labor or to engage in useful occupation for which he is qualified").

${ }^{84}$ One of the few pre-SSI state disability cases was Zunino v. Carleson, $33 \mathrm{Cal}$. App. 3d 36, ro8 Cal. Rptr. 769 (Ct. App. I973).

${ }^{85}$ Benefits were, however, usually higher under categorical disability assistance than under AFDC. See G. STEINER, SocIAI INSECURITY 24 (Ig66). In I97x, average benefit levels for ABPTD recipients ranged from a low of $\$ 50$ per month in Alabama to a high of $\$ I 77$ per month in Alaska, with a national average of $\$ 98$ per month. At the same time, average monthly AFDC payments ranged from $\$ 12$ in Mississippi to $\$ 78$ in New York, with an average of $\$ 50$. See Departament of Heatth, Education \& Welfare, Social Security Programs in the U.S. yoz03 (Y97I).

${ }^{80}$ On the differences between Social Security disability and pre-1972 categorical disability, see tenBroek \& Matson, The Disabled and the Law of Welfare, in THE LAW OF THE POOR 485, 494-96 (tenBroek ed. I966). Concerning the treatment of AFDC recipients and, by analogy, categorical disability beneficiaries, see, e.g.,

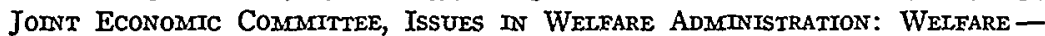
AN ADMINISTRATIVE NigHTMAaRe 26-34 (I972).

The crucial distinction between Social Security and "welfare" is appreciated by legislators and administrators:

Senator Church. Could I just underline that point by saying that in my own experience I have always noticed how differently people regard Social Security and welfare. I think I have yet to find a person who thought that his Social Security benefits were related in any way to a welfare payment. They are thought of as matters of entitlement, and since everyone does share in them, since they extend to all persons considered by the program, regardless of income, there is no feeling that there is welfare in that program. It makes a great deal of difference to so many people.
} 
entitlement, but their progression has stopped short of the place occupied by Social Security recipients.

Unlike AFDC or general relief arrangements, SSI is administered by the federal Social Security Administration, ${ }^{87}$ and cash benefits are not conditioned on a work search or acceptance of "improvement" services. Indeed, the government has undertaken to seek qualified recipients; ${ }^{88}$ and the statute and its implementing regulations emphasize entitlement rather than stigma ${ }^{80} \mathrm{Al}$ though financing of SSI through general revenues ${ }^{90}$ and the pro-

\footnotetext{
Mr. Cohen. That is why I say, Senator, one must view with very great concern the recommendations by many economists to change the financing because they look at the whole mechanism as a redistribution of income. I share their view. I am strongly for appropriate redistribution of their income through our tax system. But I want to be very careful that we don't try to inject into the Social Security system a redistribution philosophy that will ruin the public opinion support that you have just expressed which the American people have, and transform their concept of Social Security from a right into a welfare system. That would be a terrible loss.

Senator Church. I agree with you completely.
}

Hearings Before the Senate Special Committee on Aging, 93d Cong., Ist Sess., pt. 4 , at 246 (1973). Welfare recipients' attitudes mirror the publicly perceived distinction. See Briar, Welfare From Below: Recipients' Views of the Public Welfare System, 54 CALIF. L. REv. 370, 377 (I966) ("Asked whether the social worker has a right to know how the aid money is spent, sixty-six percent [of AFDC recipients] said yes. . . . And asked whether in their opinion aid should be cut off [if not being spent properly], seventy-six percent of the recipients said yes."). An early and trenchant analysis of these issues was tenBroek \& Wilson, Public Assistance and Social Insurance-A Normative Evaluation, I U.C.L.A. L. REv. 237 ( 1954 ). Interestingly, SSI has almost exactly the characteristics recommended by Briar and others for a cash-transfer program that encourages recipients to feel like "rights-bearing citizens." See Briar, supra, at 383-85; Cahn \& Cahn, The War on Poverly: A Civilian Perspective, 73 Yale L.J. I3I7, I329-3I (I964).

${ }^{87} \mathrm{See} 42$ U.S.C. \& I38Ia (Supp. III, I973); H.R. REP. No. 92-231, g2d Cong., 2d Sess. 25 (I97r).

${ }^{88}$ See N.Y. Times, Oct. 30, I973, at 22, col. 4; IIg Conc. Rec. S23,806 (daily ed. Dec. $2 x$, 1973) (remarks of Sen. Dole commending Kansas' "outreach" program); N.Y. Times, Nov. 20 , I973, at 43 , col. 2 (similar outreach program in New York State). The presence or absence of a public policy of seeking out eligible persons and notifying them of the availability of an income-support program may now be the single characteristic most typical of programs closer to right than to gratuity. See generally Note, Welfare Law - 1972 Social Security Act Amendments - Supplemental Security Income for the Aged, Blind and Disabled, 58 CORNELI L. REv. 803 (I973). Both the food stamp, see Bennett v. Butz, 386 F. Supp. I059 (D. Minn. 1974), and medicaid programs, see Woodruff v. Lavine, 399 F. Supp. 1008 (S.D.N.Y. I975), require such "outreach" efforts. No similar effort could be imagined in AFDC. In England seventy-five years ago, however, the difference between an "of right" and a "gratuitous" benefit program was whether recipients were disenfranchised. See A. V. Dicey, Lectures on the Retation Between Law and Public Opinion in England During the Nineteentr Century xxxiv$\operatorname{xxxv}$ (2d ed. IgI4).

${ }^{89} \mathrm{See} 42$ U.S.C. $\S \S$ I38I-85 (Supp. III, I973); 39 Fed. Reg. 28,626 (1974) ("conditions that are as protective of people's dignity as possible," $\$ 4$ r6.rxo(c)).

${ }^{80} 42$ U.S.C. \& I38I (Supp. III, I973). 
gram's means test ${ }^{91}$ destroy any pretense that an individual has contributed toward his own protection, a recipient is much better off than those who must rely on AFDC or general relief. SSI benefits are not only administered differently; they have been rising with the cost of living in a period when AFDC benefits have remained constant or have been reduced. ${ }^{92}$

SSI recipients are thus encouraged to feel that their nonemployment is excused, that they suffer from a sad accident of fate, and that society accepts responsibility for their support. On the other hand, everyone else who needs income support must almost by definition be a person whose poverty is his own fault. This group may be denied public income support altogether. ${ }^{93}$ Even when persons receive AFDC or general relief benefits, the checks are normally smaller than SSI payments and are often accompanied by moralistic lectures or "work requirements" that assume a propensity for indolence. ${ }^{94}$ Perhaps more important, an AFDC or general relief recipient is "on welfare," and cannot escape the message - from potential employers, from his children's teachers and friends, and from his own family - that he has failed and is supported only by the ultimate grudging charity of a stern society. ${ }^{95}$

Inherent in Congress' decision to separate the three SSI categories from AFDC must have been a notion that SSI recipients deserve better of society than those who can only qualify for AFDC.$^{96}$ The new SSI administrative arrangements translated that

${ }^{91} I d . \S 1382$.

${ }^{92}$ Even before SSI took effect, benefits were increased, Pub. L. No. 93-368, 88 Stat 422 (I973). SSI benefits now automatically increase to cover inflation. See $4^{2}$ U.S.C.A. $\$ 1382 f$ (1974).

There are several quirks in the SSI/AFDC equation. Using national standards, SSI pays at levels that seem high in Mississippi but low in California. The federal government holds a state "harmless" for case-load growth only to the extent that it supplements federal payment schedules to the levels at which the state was paying in December 1973. Thus, especially with recent high inflation, AFDC benefits in a few states are now higher than SSI levels. There are also differences in the methods of computing benefits that can make large differences to many participants. AFDC in New York pays rent plus the established support level; SSI is straight cash. With rents so high, AFDC can be a better deal. These issues are discussed in N.Y. State Assembly Standing Commitree on Social Services, Hearing Report: Problems in the Supplemental Security Income Program (r974).

${ }^{93}$ See A. LaFrance, M. Schroeder, R. Bennett \& W. Boyd, LaW of the POOR $\S \S 305,309$ (I973).

${ }^{94}$ See, e.g., New York State Dep't of Social Servs. v. Dublino, 413 U.S. 405 (I973); Calif. Welfare and Institutions Code $\$$ II300, I3650 (I972). See generally Comment, The Failure of the Work Incentive (WIN) Program, II9 U. PA. L. Rev. 485 ( 1971 ).

${ }^{05}$ See note 86 supra.

96 " $[Y]$ our committee believes that the American people do not want a system 
statutory assumption into more favorable benefits and less onerous procedural requirements for SSI recipients. But how did Congress define the subgroup of the needy who should receive this special treatment?

\section{B. SSI: The Qualification Questions}

In composing a statutory definition of SSI disability, Congress tracked the language that now describes Social Security disability qualification. An applicant must be "unable to engage in any substantial gainful activity by reason of any medically determinable physical or mental impairment" likely to result in death or extend for twelve months; ${ }^{27}$ and medical inability to work is to be determined "regardless of whether a specific job vacancy exists for him or whether he would be hired if he applied for work." ${ }^{88}$ But, as was argued above, the important fact about Social Security disability is its coverage of those who have won a place in the labor force and been struck from it by medical tragedy. Thus Congress' use of the Social Security disability definition in the SSI law was psittacistic. SSI can take Social Security's words but not its meaning, because the SSI test will generally be applied to persons who have never worked.90

The distinction between the two programs can be illuminated by considering the eligibility of a person in the job gap. Such an applicant will be someone whose medical impairment prevents attainment of his full potential as a worker, who can nonetheless do some work, but who finds none. With respect to Social Security disability, it was argued above that the clarifying question ought to be whether all workers should be able to feel secure against income loss occasioned by medical disability in an unfavorable labor market. Under this test, and under Kerner, the job gap applicant would receive Social Security disability benefits if he has a record of sufficient prior work at covered employment. Under SSI, however, the touchstone of expectation that requires Social Security disability coverage is not available, because SSI appli-

which results in promoting welfare as a way of life. [Therefore, we have attempted to provide] adequate assistance to those who cannot help themselves, while ... maximiz[ing] the incentive and the obligation of those who are able to work to help themselves." H.R. REP. No. 92-23I, 92d Cong., 2d Sess. 2 (I97I).

${ }^{97} 42$ U.S.C. $\& 1382 \mathrm{C}(3)$ (A) (Supp. III, I973).

${ }^{98} I d$. $\& I 382 \mathrm{C}(3)(\mathrm{B})$.

${ }^{90} \mathrm{~A}$ hint that the plagiarized definition is a result of bureaucratic routine rather than legislative choice is its use again when Congress almost enacted an income tax exemption for the disabled in 1971. See H.R. REP. No. 92-708, 92d Cong., 2d Sess. 49 (I97I). 
cants will generally have failed to establish a place in the workforce. $^{100}$

As the SSI statute is currently written, ineligibility of job gap claimants is clear. Congress' incorporation into SSI of the postKerner Social Security disability definition denies benefits to such persons. In deciding whether SSI exclusion is appropriate, it is useful to note the differences between the SSI welfare estate and that just below - the work-search and employment lecture requirements. The absence of these requirements in SSI indicates that SSI recipients ought to be persons for whom such requirements are otiose. Thus, if an individual can work, SSI tells him that he should be making the same efforts as one with no medical explanation for his decline but similar skills and prospects. On the other hand, the SSI program does seem to accord special social legitimacy to the persons it benefits, and medical infirmity is the key to this favored status. But since ability to work, and thus to "profit" from work-search requirements, also seems to be a consideration in SSI's exclusion of the partially disabled, it is perhaps defensible to conclude that a person thrust into the job gap by a medical occurrence who can still work should be ineligible for SSI disability.

A number of other outcomes required by the current SSI statute are not so easily comprehended. Consider the following cases:

(I) the person who suffers a terrible automobile accident at age 16 , will be in bed for years, and will be unable to earn the minimum wage;

(2) the person born with very low levels of intelligence and physical coordination, who will be at the end of every job queue, and will work only if the economy achieves something approaching full employment;

(3) the mother of two children under four, whose husband, a student, dies of a heart attack; she could work, but her wages will not defray the cost of child care, ${ }^{101}$ and no subsidized daycare facility is available;

(4) the heroin addict who has on four separate occasions en-

${ }^{100}$ There is an overlap between SSI and Social Security, however. Nearly half a million Social Security disability beneficiaries receive so little that they also qualify for SSI. See Mathews v. Eldridge, 44 U.S.L.W. 4224, 423 I n.27 (U.S. Feb. 24, I976). These persons are permitted to disregard only the first twenty dollars per month of Social Security benefits in calculating their SSI "need." See 42 U.S.C. $\S$ I382a(b) (2) (Supp. III, I973).

${ }^{101}$ See C. Schultze, E. Fried, A. Riviti \& N. Teeters, Serting National Priorities: The I973 Budget 256-85 (Brookings Inst. I972). 
tered a methadone program, become stabilized, started work, suffered emotional turmoil, quit the job, and then resumed heroin abuse.

The SSI statute provides disability benefits only in Case ( $I$ ). Case (2) may approach mental retardation, and if the doctors are willing to describe the individual as mentally impaired, the hearing officers will award disability benefits. But, as the individual is described here, he is not sick but is "only" someone who will almost never be employed in our economy. Therefore he may be eligible for AFDC or general relief, but he cannot qualify for SSI.

The mother in Case (3) is in no way physically afflicted. Her need is not caused by a permanently high-unemployment economy. She is a single parent, in a society that incongruously emphasizes the importance of both work and child care while providing insufficient publicly subsidized facilities for the children of working parents. ${ }^{102}$ Although she is the paradigm case for AFDC benefits, when she seeks those benefits she will be entangled in what will seem to her a bureaucratic nightmare: work requirements but few jobs, and no suggestions for care of the children.

Case (4) is more complicated. The American Psychiatric Association says heroin addiction is a disease, ${ }^{103}$ but the SSI statute requires whole-hearted participation in a treatment program. ${ }^{104}$ This individual is capable of that, but not steadily. When he is in treatment, he can work. But, before long, he is likely to resume drug abuse. Taking only SSI's general qualification clauses, this might be a difficult case. Is the addict "unable" to work or only unwilling? Is his shortcoming a "medically determinable . . . impairment" or only a severe emotional maladjustment? Is the inability sufficiently permanent? Congress has, however, specifically required treatment of those addicted to alcohol and drugs as a condition of SSI eligibility. If comprehensible at all, these requirements must represent a legislative judgment that there cannot be an "inability" to participate in treatment, or at least that no such inability can be a sufficiently "medical" failing.

Thus the distinctions required to select the persons who are disabled from those who are merely in need must reflect two different sorts of public judgments. First, they show a policy of

${ }^{102}$ Cf. Loveless v. Weinberger, 492 F.2d 129I, I293 (6th Cir. 1974) (denying Social Security coverage for a quarter in which claimant took care of her grandchildren, and rejecting the argument that "the first and most important 'trade or business' of plaintiff's daughter . . . was to care for her minor children").

${ }^{103}$ See Computtree on Nomenctature and Statistics of the AMerican Psychiatric Association, Diagnostic and Statistical Manual of Mental. DisORDERS 92 (2d ed. Ig68).

${ }^{104} 42$ U.S.C. \& $1382(\mathrm{e})(3)$ (Supp. III, 1973). 
imposing work rules on needy persons who are healthy enough to work. The restrictions may be difficult or impossible to administer successfully. They may be a poor substitute for incentive arrangements by which work would pay better than non-work. But, if we are unwilling to raise low wages substantially, and also unwilling to reduce AFDC and general relief benefit levels, many welfare recipients will have no financial incentive to obtain jobs. We respond to that problem by giving benefits only on a showing of work-search, and by denying them on certain showings of unjustified refusal of or departure from work.

If this were the only purpose of the administrative requirements attached to the remaining non-federalized assistance programs, SSI disability would have a clear focus. It would be the category of those who ought not be subjected to work-search: because we will pay them whether they look or not; we are positive they will not find anything; or, on balance, we would just as soon not have them working. ${ }^{105}$ So defined, SSI would include all the

105 The matter is not quite this simple. The Social Security program has never sought to discourage eligible persons from obtaining benefits, and indeed has had a positive goal of enticing persons beyond retirement age from the labor force. See 42 U.S.C. $\$ 403$ (1970). SSI is, among other things, a "welfare" program, and therefore a category which everyone should seek to avoid. To help persons escape SSI, the program "taxes" attempts to achieve economic independence quite mildly. See id. $\S \mathrm{I382a(b)} \mathrm{(4)} \mathrm{(Supp.} \mathrm{III,} \mathrm{I973).} \mathrm{Thus} \mathrm{a} \mathrm{person} \mathrm{must} \mathrm{be} \mathrm{entirely} \mathrm{unable} \mathrm{to} \mathrm{work}$ in order to qualify for SSI disability benefits, but can then become able to do some work and still retain some of his SSI benefits as he achieves a low income. These provisions expose apparently conflicting public goals: the requirement of absolute dependency as a condition of qualification, yet the rejection of arrangements, e.g., a roo percent tax, that might discourage work efforts. But the goals are not necessarily in conflict. Consider, for example, the cases of physically handicapped persons who can work productively with training, emotional support, and workplace adjustments. Or consider persons with past or present alcohol and drug problems, who can move gradually toward capacity and dignity if supported in the right way. For many such persons, a cost-benefit analysis will not justify the amount of remedial service needed to permit labor-force participation. The government would gain financially if it declared these persons disabled and supported them, rather than taking the steps necessary to permit them to work. Yet other values dignity, equity, justice - argue for rehabilitation expenditures, which should be seen as a public obligation to the disabled individuals rather than as prudent conservation of the fisc. See generally Farber, The Handicapped Plead for Entrance -Will Anyone Answer? $64 \mathrm{KY}$. L.J. 99 (I975). It may be that a stated separation between the disabled and the unemployed, the two groups divided by society's conclusion about whether they need work, would hinder some rehabilitative efforts that are assisted by the fuzzy overlaps among existing programs. But, at least in theory, it is possible for society's attitude toward the disabled to be: "You need not work; minimal support is available; but if you desire rehabilitation, it too is available; and it will seek to bring you to the highest possible level of capacity." Such a policy could, for example, justify public expenditures for child care services that permit mothers to work, even where their earnings are less than the cost of child care. See note Ior supra. 
cases described above. In cases (I), (2), and (4) work incentives are more trouble than they are worth for both the administrators and the recipient. The mother in case (3) ought not be required to seek work because she can do more social good at home than in a low-wage job. But SSI does not go this far, because it applies only to persons with a "medically determinable" inability to work. A policy of encouraging work cannot explain this restriction, because SSI denies benefits to many persons whom any sensible inquiry would classify as extremely unlikely to achieve a place in the workforce.

The boundaries of SSI must therefore reflect a second factor, a moral judgment. In this view, the program describes not only persons who cannot work, but persons whom we are willing to anoint as legitimately unable to work. The requirement of "medical" disability functions to demarcate those whose poverty is sympathetic from those who are poor without excuse. We say of those medically unable to work that their circumstance deserves more sympathy, and more money, than the circumstance of others whose economic situation is as desperate but whose reason is different. Thus this law creates not only economic outcomes, and not only bureaucratic arrangements for carrying out its economic policies, but also a further refinement of the system of socially and morally explicit categories into which welfare laws distribute the citizenry.

\section{SSI as an Attempt to Confer Social Status}

Stating that SSI disability assigns a status does not explain why the line has been drawn where it has. Deterrence alone is not a sufficient explanation. The persons represented by cases (I), (2), (3), and (4) appear equally unable to affect their present circumstances, and yet only case (I) qualifies for SSI. Perhaps we fear that the availability of unstigmatized benefits will encourage undesirable conduct in the future. "Medical" may thus be shorthand for events entirely outside the influence of an individual, and thus entirely unaffected by the possible incentive effect of relatively generous income support. As a factual matter, however, such an assumption seems dubious. Cases (2), (3), and (4) seem consequences of general social and cultural phenomena more than of individual planning. Our society may revere medicine and sympathize with the sick, but it holds no views that could explain distinctions between persons totally unable to work according to whether their condition results from an illness or, on the other hand, from limited natural abilities, decades of racism or sexism, homosexuality, family burdens, technological change, a broken home, or national fiscal policy. 
A better explanation is that the categories SSI creates are assigned classifications of social standing, a modern version of the traditional estates real that classified individuals according to their relationship to the land. ${ }^{106}$ SST thus implements fundamental choices by Congress about the nature of the relationship that a large group of citizens should have to each other and to the state. Congress could have brought old, blind, and disabled low-income persons within Social Security. It rejected this alternative presumably because it would have destroyed a distinction believed important - that between insurance and welfare. A second alternative was also rejected. Benefits for those of the poor who are old, blind, or disabled could have been increased without altering the structure of the former categorical programs. But Congress was plainly ready to make a social value judgment about these persons, to declare their poverty to be a matter largely beyond their individual control, and to accept national responsibility for their support. ${ }^{107}$ A preference was expressed, legislatively and then administratively, for the social benefits of unstigmatized, reliable income support for this large group of recipients. ${ }^{108}$

When the society assigns a status such as SSI eligibility, it

${ }^{106}$ See Reich, The New Property, 73 YaLE L.J. 733 (I964); Reich, Individual Rights and Social Welfare: The Emerging Legal Issues, 74 YALE L.J. I245 (I965). See also E. GofrMan, StrGMa 137 (paperback ed. r969):

Although these proposed philosophies of life, these recipes of being, are presented as though from the stigmatized individual's personal point of view, on analysis it is apparent that something else informs them. This something else is groups, in the broad sense of like-situated individuals, and this is only to be expected, since what an individual is, or could be, derives from the place of his kind in the social structure.

One of these groups is the aggregate formed by the individual's fellowsufferers ....

${ }^{107}$ For a prescient argument that the distinction between employable and unemployable welfare recipients, while crude, is useful because the taxpaying public has more difficulty accepting welfare programs that benefit employable persons, see Handler \& Hollingsworth, Work, Welfare, and the Nixon Reform Proposals, 22 StaN. L. Rev. gO7 (I970).

${ }^{108}$ Obviously it would be wrong to assume that a "disabled" stamp can be placed on a person without stigmatizing him. See Maclean \& Jefferys, Disability and Deprivation, in Poverty, Inequality and Class Structure 165 , I72 (D. Wedderburn ed. 1974). The real questions are the conduct to be approved and encouraged by particular social categories, the groups thereby to be formed for political contest, and the attitudes categorized persons are to be permitted to take to themselves. In Goffman's language:

It should be plain that . . advocated codes of conduct provide the stigmatized individual not merely with a platform and a politics, and not merely with instruction as to how to treat others, but with recipes for an appropriate attitude regarding the self. To fail to adhere to the code is to be a selfdeluded, misguided person; to succeed is to be both real and worthy ....

E. Gofmanan, supra note I06, at 135. Accepting difficulties in applying concepts such as these to real-world facts, it seems fair to conclude that SSI is a step forward for persons covered, but that its existence may make life more difficult for persons remaining under AFDC. 
tells a person how he should regard himself and how he should conduct some of his relationships with others. ${ }^{100}$ Thus when the SSI groups were separated from AFDC recipients, but not given quite the same treatment as Social Security participants, SSI recipients were told that they too had a group to look down upon, but that they still had to look up at those who have worked. As the statute classifies the population into sub-groups officially determined to be appropriate, it gives SSI recipients a regular income and a shred of legitimacy at the expense of the reclassification of those below them, who have once again failed to achieve recognition.

SSI can therefore be seen as an attempt to transfer, in its definition of disability, nonmonetary benefits to recipients through the knowledge that a substantial group has been judged less worthy. Indeed, an important determinant of Social Security policy has been a widely held belief that recipients' feelings of entitlement and legitimacy depend on exclusion of the undeserving.

But if welfare categories are drawn in a way that divides the population according to rankings of moral legitimacy, the bounds of the categories must be tested against a larger scheme of shared values, a test the new SSI definition cannot pass. The significance of SSI is that it exempts its recipients from worksearch requirements and legitimates dependency with its implicit declaration that recipients are out of work for approved reasons. Yet, as we have seen, all four of the example cases, as well as the medically disabled, are persons we ought to spare from work requirements. All four should therefore receive minimal income support without proving their willingness to work and should be designated as excusably removed from the working population.

If we are to take seriously Congress' creation of an intermediate social welfare estate in SSI, one between the state-created expectations of Social Security recipients and the plight of the undeserving poor, then the current limitation of SSI benefits to those who are totally disabled by medical causes should be abandoned. Congress should be regarded as having said that our society has one form of insurance that attaches to wage-earners when they work and pay Social Security taxes, and that we now have another form, SSI, that is applicable at birth to all citizens.

${ }^{109}$ See E. GofFMAAN, supra note I06, at $\mathrm{r} 68$ :

The member who is defined as physically sick is in somewhat the same situation [as the member of a group who is authorized to be deviant because he is regarded as eminent]; if he properly handles his sick status he can deviate from performance standards without this being taken as a reflection on him or on his relation to the group. The eminent and the sick can be free, then, to be deviators precisely because their deviation can be fully discounted, leading to no re-identification; their special situation demonstrates they are anything but deviants - in the common understanding of that term. 
The SSI estate is financed by general taxes and should protect those people who - it is generally felt - ought to receive benefits because they have been victims of occurrences that might strike any person, and because we are prepared to say that these persons need not work. Even if the economy were running well, and jobs were available for all who wanted them, we would not expect these persons to work; or at least we would be willing to support them whether or not they sought to work. ${ }^{110}$ The logic of SSI thus requires that the income support commitments undertaken in that program be extended to all those whom we do not expect to work but who are excluded by SSI's arbitrary "medical" qualification.

${ }^{110}$ The distinction is at least 300 years old. For example, the Old Poor Law, 43 Eliz., c. 2 (I60r), distinguished between "( $I$.) the children of parents unable to keep and maintain them; (2.) such persons who, having no means to maintain themselves, used no ordinary and daily trade of life to get their living by; (3.) the lame, impotent, old, blind, and such others as were poor and not able to work. The first two of these classes were to be relieved by being set to work. The third alone were to be relieved without work." Attorney-General v. Guardians of the Poor of the Merthyr Tydfil Union, [Igoo] I Ch. 516, 54x. 